\title{
GEODYNAMICS AND EVOLUTION OF THE MIOCENE MINERALISATION IN THE CYCLADIC - PELAGONIAN BELT, HELLENIDES
}

\section{N. SKARPELIS ${ }^{1}$}

\begin{abstract}
The paper aims to provide a sound account of the type of Miocene mineralisations in the Cycladic-Pelagonian belt and their relationship with the geodynamic evolution of the area. Skarn and manto types, epithermal precious and base metals mineralisation, and vein magnesite in ultramafics are associated to distinct stages of the geodynamic evolution of the belt. Extensional tectonics favoured their generation. Late stages of extensional tectonics resulted in the formation of vertical to subvertical NW-SE trending fault zones, which were then used as conduits for ascending hydrothermal fluids. The relationship between the geodynamics and the metallogenetic evolution of the belt is discussed on the basis of available data on the geology of four critical areas: Tinos and Mykonos islands, Laurium and Northern Euboea.
\end{abstract}

KEY WORDS: Cyclades, Pelagonian, Laurium, Euboea, precious metals, epithermal mineralisation, Late Miocene, extension, granitoids, skarns, manto, vein magnesite

\section{INTRODUCTION}

The central and northern Cyclades and the island of Euboea are part of the Cycladic - Pelagonian Belt. Numerous mineral occurrences and ore deposits are localised into the belt. Several of them were exploited in ancient times (Sifnos, Laurium, Kythnos) and during the $19^{\text {th }}$ and $20^{\text {th }}$ centuries (Laurium, Serifos, northern Euboea). The Miocene Cycladic - Pelagonian mineralisations are part of the Tertiary - Quaternary metallogenetic province in the Aegean, which extends from the Rhodope belt to the south Aegean volcanic arc.

During the last 20 years some very important studies were published on the geodynamic evolution of the Cycladic - Pelagonian Belt, combining structural, petrologic and radiometric dating methods. The geology of individual mineralised outcrops in the Cyclades is poorly studied. Even for the famous Laurium deposit several metallogenetic models are proposed. Research work on the mineralisations in the area has been fragmental. The works on Laurium by MAPINO $\Sigma$ \& PETRASCHECK (1956), on Tinos by MELIDONIS (1980) and Serifos by SALEMINK (1985) are outstanding.

The present study was initiated when it was understood that many of the mineralisations are spatially associated with certain magmatic rocks and tectonic structures and temporally associated with certain stages of the geodynamic evolution of the area. It was also realised that the formation of the massive sulfide ores of Laurium and the vein-type magnesite deposits in northern Euboea, due to the generation and circulation of a substantial volume of fluids, ought to be related to some distinctive processes in the Earth's crust, bearing an important geodynamic significance.

The paper aims to provide a sound account of the type of mineralisations and their relationship with the geodynamic evolution of the area, although the lack of absolute age determination data makes this effort difficult. The study will provide the background for further research on the relationship between geodynamic evolution, generation and migration of fluids, and the genesis of - clearly distinct in time and space - mineralisations within the crust and on the near surface. So, this approach adds to the history of geodynamic evolution of the area. However, it definitely completes the scheme of metallogenetic evolution of a large part of the Aegean, during the time period from Tertiary to recent: Oligocene porphyry $\mathrm{Cu}$ - $\mathrm{Au}, \mathrm{Fe}$-Cu skarns and carbonate-hosted $\mathrm{Pb}-\mathrm{Zn}$-Ag-Au replacement deposits in the Serbomacedonian and Rhodope belt (e.g. Skouries, Madem Lakkos Olympias, Xanthi, Maronia), epithermal Au deposits associated with the Oligocene volcanism in Thrace (e.g. Perama, Sappes, Agios Filippos), Miocene epithermal - type mineralisations in the northern Aegean islands (Lemnos, Chios, Lesbos), epithermal - type mineralisations associated with the south Aegean volcanic arc (Milos, Nysiros).

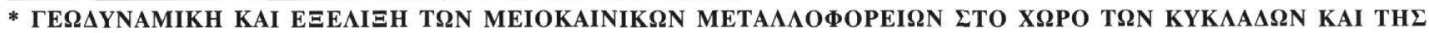

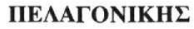

${ }^{1}$ Department of Geology, Section of Economic Geology \& Geochemistry, University of Athens, Panepistimioupoli, 15784 Zografou, Athens. e-mail: skarpelis@geol.uoa.gr
} 


\section{REGIONAL GEOLOGICAL SETTING}

The Aegean region has witnessed a prolonged history of convergence and collision between the African and Eurasian plates. The stacked sequences of individual nappes and thrust sheets in the Cycladic - Pelagonian Belt can be grouped into two major tectonic units (for summaries see DURR et al., 1978; BLAKE et al., 1981; MOUNTRAKIS, 1986; KATSIKATSOS et al., 1986; SCHLIESTEDT et al., 1987; PAPANIKOLAOU, 1987; ENGEL \& REISCHMANN, 1999; VAVASSIS et al., 2000; LIPS, 1998; and references quoted therein):

- The Lower Tectonic Unit (LTU) comprises two parts: a minor sequence of pre-Alpine crystalline basement, outcroping in Flambouron, Euboea, Paros, Antiparos, Naxos, Sikinos, Ios and Delos, and a metamorphosed sequence of Permian to Mesozoic carbonates, metasediments and metavolcanics. Metabauxites (emeries and diasporites) and metamorphosed $\mathrm{Mn}(-\mathrm{Fe})$-rich sediments are hosted within the latter part of the Unit. Two stages of regional metamorphic events are recognised within the lower main sequence: 1. An Eocene (c. 50-40Ma) high-pressure/low-temperature metamorphism at eclogite to blueschist facies conditions and 2. An Oligocene-Miocene (25-20Ma) Barrovian-type, greenschist to amphibolite facies overprint, with local migmatization. The HP sequence is extended from Milos (KORNBROBST et al., 1979) and Thera (SKARPELIS \& LIATI, 1990) to S. Euboea (BAVAY \& ROMAIN-BAVAY, 1980) and the Thessaly (SCHERMER et al., 1989).

- The Upper Tectonic Unit (UTU), which was not affected by the Tertiary high-pressure metamorphism, comprises a sequence of unmetamorphosed Permian to Mesozoic sediments and late Cretaceous sedimentary and igneous (including ophiolitic) rocks, metamorphosed under medium-P/high-T conditions and dismembered ophiolites. Small subeconomic chromite bodies in serpentinites, deposits of green marble, occurrences of talk and vein type magnesite deposits are associated with the UTU.

Intrusion of granitoids at shallow crustal levels caused contact metamorphism of parts of both the lower and the upper tectonic units. Dating of the granitoids indicates different magma pulses within the late Miocene.

\section{THE CYCLADIC - PELAGONIAN MINERALISATIONS}

Our recent studies allow a classification of the Miocene Cycladic - Pelagonian mineralisations to four major ore deposit types: Their geographical distribution is shown in Fig. 1.

- Skarn-type, within the contact metamorphic aureoles of granitoids (e.g. Serifos, Thera, Laurium). They are subeconomic classified within the calcic magnetite group. The pressure (depth) of emplacement of the granitoids and the pressure and temperatures of formation of the contact metamorphic rocks are summarised in Table 1a.

- Manto-type $e^{2}$ (e.g. Laurium, Sifnos).

- Epithermal precious and base metals quartz- and barite-veins. They are associated with steeply dipping, brittle normal faults, which affected the metamorphic rocks, the Miocene granitoids and the Tertiary sediments. A first interpretation of the back-arc setting of the mineralisation is given by SKARPELIS \& AVIGAD (2000). Deposition of the subeconomic precious- and/or base metals mineralisation in Myconos, Tinos, Antiparos, Kythnos, Andros and south Euboea island is attributed to that mineralising event. The main features of the epithermal vein type mineralisations are summarized in Table $1 \mathrm{~b}$.

\section{- Vein-type magnesite deposits within the ultramafic rocks of Northern Euboea.}

On the basis of the available data, four areas are considered as critical for the study of the relationship between the geodynamics and the metallogenetic evolution of the Cycladic-Pelagonian belt. The association of each one of the above deposit types to distinct stages of the geodynamic evolution of the Cycladic-Pelagonian Belt is evident in Tinos and Mykonos islands, in Laurium area and in Northern Euboea.

\footnotetext{
${ }^{2}$ We use the term "manto-type" as it was restricted by BEATY et al (1986) to denote massive sulfide ore (Ag, $\left.\mathrm{Pb}, \mathrm{Zn}, \pm \mathrm{Cu}\right)$ with replacement characteristics, generally stratabound, blanket to pipelike in carbonate host rocks
} 


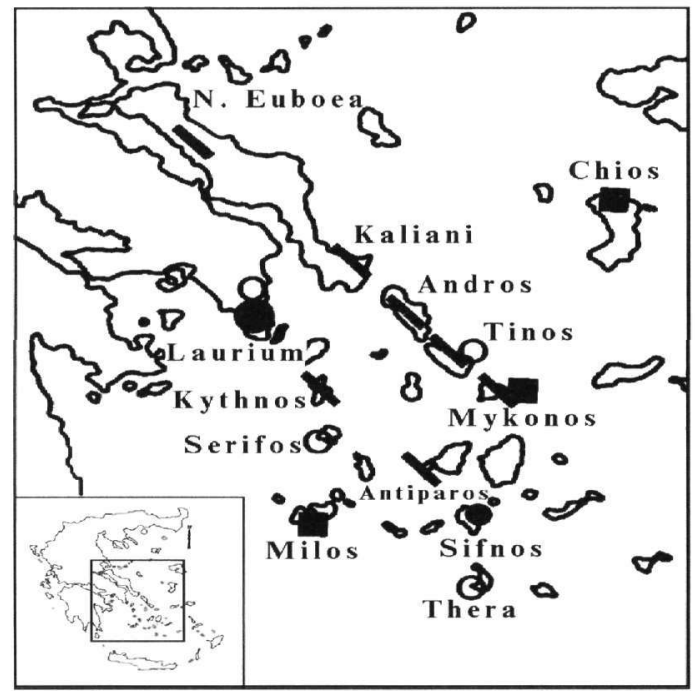

Fig.1. Geographical distribution of Miocene ore deposit types in the Cycladic - Pelagonian belt: carbonate-hosted massive sulfides (solid circle), epithermal-type (rectangular), skarns (open circle), epithermal veins (bar).

Table 1a. Pressure of emplacement of the granitoids and pressure and temperatures of formation of contact metamorphic rocks in the Cyclades*

\begin{tabular}{|l|l|l|l|l|l|}
\hline \multicolumn{6}{|c|}{ Cable 1a. Pressure of emplacement of the gr anitoids and pressure and temperatures of formation of } \\
intrusives and contact metamorphic rocks in the Cyclades*
\end{tabular}

\section{a. Tinos island: From granite emplacement and skarns to mineralised ductile-brittle faults}

On Tinos the LTU comprises mainly Mesozoic sediments and volcanics metamorphosed at high pressure conditions. The sequence was subdivided roughly by means of three marble units by MELIDONIS (1980). Detailed studies on the petrology and geochronology of the HP rocks were carried out by BROECKER (1990), BROECKER et al. (1993), BROECKER \& FRANZ (2000). On the basis of petrological and structural criteria the Basal unit, exposed in NE Tinos, consisting of metamorphosed carbonates and phyllites, was interpreted by AVIGAD \& GARFUNKEL (1989) as a tectonically separated subunit. The UTU comprises dismembered ophiolites (meta-gabbros, serpentinised untramafics), ophicalcites, and phyllites yielding Upper Cretaceous metamorphic ages (MELIDONIS, op. cit.; KATZIR et al., 1996). The setting of the Cretaceous amphibolite facies rocks (amphibolites, gneisses and impure marbles) of the Akrotiri Unit (PATZAK et al., 1994) in relation to the other Units in Tinos is uncertain. A low-angle normal fault juxtaposed low-pressure metamorphic rocks of the UTU over blueschists and eclogites of the LTU. A detachment fault separates the Basal unit of the island from the blueschists (AVIGAD \& GARFUNKEL, op. cit.). Both the LTU and the UTU were intruded by plutonic rocks. The major part of the plutonite is a monzogranite. Garnet-bearing leucogranites occur at the outer parts of the plutonic body towards the regionally metamorphosed rocks. Aplitic dykes intrude the plutonic 
and the country rocks. The age of emplacement of the plutonic rocks is $\mathrm{c}$. $14 \mathrm{Ma}$, as evidenced by $\mathrm{K} / \mathrm{Ar}$ dating of hornblende and $\mathrm{Rb} / \mathrm{Sr}$ dating of whole rock and biotite (ALTHERR et al., 1982; BROECKER \& FRANZ, 1998). Fission track dating for titanite and apatite provided ages of $13.8 \pm 2.1$ and $10.8 \pm 1.3 \mathrm{Ma}$ respectively (ALTHERR et al., op. cit.).

Using the Al-in-hornblende geobarometer, pressures between 3.7 to $4.2 \mathrm{~kb}$ were obtained for samples of the monzogranite. Temperatures in the contact aureole were $660^{\circ} \mathrm{C}$ close to the granite contact, to about $475^{\circ} \mathrm{C}$ in peripheral zones. The Pressure for the intrusion of the monzogranite during the thermal overprint was estimated at about $3 \mathrm{~kb}$ (BROECKER \& FRANZ, 1994).

A compressive stress regime (evidenced by structural data on parts of the monzogranite) began gradually to turn extensional (evidenced by structural data in the NE part of the plutonic body) (BORONKAY \& DOUTSOS, 1994). The geochemistry of the monzogranite is indicative of an emplacement in a compressive regime, whereas the associated leucogranite bodies display geochemical insignia suggesting that the tectonic regime was evolved towards extension (MASTRAKAS \& SEYMOUR, 2000).

The contact metamorphic aureole in Tinos lacks significant mineralisation. Minor scheelite mineralisation was reported by PAPASTAVROU \& PARITSIS (1990). Scheelite is mainly associated with garnetites of the main skarn stage. A quartz-magnetite sample from a contact metamorphic skarn gave an oxygen isotope temperature of $555^{\circ} \mathrm{C}$ and calculated water composition of $9.1 \%$. The value of $\delta^{18} \mathrm{O}$ from this water is consistent with a primary magmatic fluid (BROECKER et al., 1993).

Subvertical undeformed, NW-SE trending dacitic dykes (MELIDONIS, 1980), which crosscut both the upper and the lower units and penetrate the detachment, yielded an average $\mathrm{K} / \mathrm{Ar}$ age of $11.5 \pm 0.4 \mathrm{Ma}$ (AVIGAD et al., 1998).

Two generations of mineralised veins were explored at the NE part of the island (Lardiades - Panormos) and the central west part (Apigania). They crosscut dolomitic marbles of the Basal unit, the blueschists and the detachment fault between the Basal unit and the blueschists. The thickness of individual veins is less than $0.5 \mathrm{~m}$.

Table 1b. Main characteristics of epithermal Late Miocene extension veins in the Cyclades

\begin{tabular}{|c|c|c|}
\hline & Mode of occurrence & Host lithology and alteration \\
\hline Mykonos & $\begin{array}{l}\text { - Subvertical NW-SE veins filled with barite and } \\
\text { (ox.) sulfides, associated with extensional faults } \\
\text { (tension gashes). } \\
\text { - Epithermal silica cap and silica breccia with } \\
\text { subeconomic Au. } \\
\text { - Stockworks of barite within the molasse }\end{array}$ & $\begin{array}{l}\text { The Miocene granite and the upper } \\
\text { Unit (molasse and greenschists). } \\
\text { Silicification - argillic alteration of the } \\
\text { wall rocks }\end{array}$ \\
\hline Tinos & $\begin{array}{l}\text { Two generations of quartz(-sulfide) veins: a. } \\
\text { Veins formed at the ductile stage, striking E-W } \\
\text { and b. Veins associated with NW-SE trending } \\
\text { faults generated under brittle conditions. The } \\
\text { veins crosscut the detachment fault between the } \\
\text { Basal unit and the blueschists. Precious and } \\
\text { base metals. Epithermal stage of deposition. } \\
(1,2)\end{array}$ & $\begin{array}{l}\text { Marbles of the Basal Unit } \\
\text { Marbles of the blueschist unit } \\
\text { Talc formation at the expense of dolo- } \\
\text { mitic marble }\end{array}$ \\
\hline Antiparos & $\begin{array}{l}\text { Subvertical NW-SE quartz veins. } \\
\text { Minor base metals, } \mathrm{Ag} \text { and } \mathrm{Au} \text {, } \\
\text { Minor barite }\end{array}$ & $\begin{array}{l}\text { Gneisses and marbles of the Marathi } \\
\text { Unit (known from Paros) } \\
\text { Argillic alteration of wall rocks, ankeriti- } \\
\text { sation of marbles }\end{array}$ \\
\hline Kythnos & $\begin{array}{l}\text { - Subvertical veins of NW -SE direction. Deeply } \\
\text { oxidised massive sulfide ore enriched in Cu. } \\
\text { Minor barite (Thermes, Zogaki, Georgios, Lef- } \\
\text { kes). } \\
\text { - Thick quartz veins (NW part of the island). } \\
\text { Minor base metals and Au, minor barite. }\end{array}$ & $\begin{array}{l}\text { Marbles of the blueschist unit of the } \\
\text { island. Minor marble replacements. } \\
\text { Ankeritization of marbles. }\end{array}$ \\
\hline Andros & $\begin{array}{l}\text { NW-SE striking quartz veins. } \\
\text { Minor base metals sulfides }\end{array}$ & $\begin{array}{l}\text { Blueschists overptinted by HT/LP } \\
\text { metamorphism } \\
\text { Silicification and argillic alteration of } \\
\text { wallrocks }\end{array}$ \\
\hline $\begin{array}{l}\text { Kaliani } \\
\text { (South } \\
\text { Euboea) }\end{array}$ & $\begin{array}{l}\text { Quartz veins striking NW -SE dipping } 45-55^{\circ} \mathrm{NE} \text {, } \\
\text { thickness } 0.1 \text { to } 1.5 \mathrm{~m} \text {. } \\
\text { Base metals sulfides, native Au (3). } \\
\text { Associated with faults possibly generated at the } \\
\text { transition from the ductile to brittle stage }\end{array}$ & $\begin{array}{l}\text { South Euboean blueschists (metapeli- } \\
\text { tes, marbles, metabasites) } \\
\text { Sericitic alteration of the wall rocks, sili- } \\
\text { cification. }\end{array}$ \\
\hline
\end{tabular}


They are associated with faults generated at the transition from ductile to brittle deformation. The first generation of quartz veins, striking E - W, formed early at the ductile stage. A swarm of quartz - sulfides veins are roughly of the same strike (NW - SE) as the dacitic dykes of $11 \pm 0.4 \mathrm{Ma}$ age. The mineralisation was evolved during that transition: milky quartz deposited at the ductile stage, whereas grey quartz, sulfides and sulfosalts were deposited at NW-trending open fissures. Their complex mineralogical composition was studied by MELIDONIS (1980) and TOMBROS \& SEYMOUR (1998): quartz, pyrite, chalcopyrite, sphalerite, pyrrhotite, galena, tetrahedrite, arsenopyrite, argentite, acanthite, proustite, polybasite, electrum, rammelsbergite, cassiterite, canfieldite are the main minerals identified. Fluid inclusion studies were performed on sphalerite and milky quartz. The first mineral to precipitate was clear quartz $\left(220-200^{\circ} \mathrm{C}\right)$, followed by sulfides and sulfosalts deposited at temperatures between $190^{\circ}$ to $150^{\circ} \mathrm{C}$. Salinities range between 0.5 to 6.5 (average 3.5 equiv. \% NaCl). The mineralisation was possibly deposited from ascending hydrothermal fluids of magmatic origin diluted by meteoric water (TOMBROS \& SEYMOUR, op. cit.).

\section{b. Laurium: From granite emplacement and skarns to polymetallic manto-type massive sulfide ore}

Geology: The SE part of Attica peninsula (Lavreotiki) is characterised by a Lower Mesozoic metamorphic para-autohthonous sequence of marbles with a metaclastic horizon in between (Kaesariani schists). A Tertiary age (pre-upper Miocene) is assumed for the regional metamorphism of the system. The sequence is thrust by the allocthonous system (alternatively termed phyllite nappe). An Upper Cretaceous age is postulated for a part of the system, on the basis of fossil findings discovered in carbonate rocks by LELEU \& NEUMMAN (1969). The thrust plane brings the allocthonous system in contact with various horizons of the upper marble, the Kaesariani schists or the lower marble. The mineralogy, petrochemistry and $P-T$ path of metabasic rocks (prasinites) within the system were studied by BALTATZIS (1996). He concluded they range in composition from basalts to trachyandesites and experienced a progressive transformation of possibly eclogite facies rocks through epidote blueschists into greenschists. Those prasinites are part of the Cycladic blueschist unit. Neogene sediments comprise lacustrine and brackish deposits (conglomerates, sandstones, marls and minor carbonates).

Deformed granodioritic and acidic intrusives forming small sills and lacoliths are found mainly within the phyllites of the allocthonous system close to the thrust plane and along the thrust contact between the two systems. Aplitic sills were observed both within strata of the autocthon and the allocthon systems. Syntectonic deformation affected the rocks (PAPANIKOLAOU \& SYSKAKIS, 1991), indicating that intrusion of magma took place since the time of final emplacement of the allocthon over the autocthon. A stock of an undeformed upper Miocene I-type granodiorite is exposed in Plaka area. An intrusion age around $10 \mathrm{Ma}$ was proposed for the granodiorite on the basis of K-Ar dating of biotite (MARAKIS, 1968). A K/Ar whole rock dating indicated 8.8 \pm 0.5 Ma (MARINOS, 1971), whereas Fission Track dating of apatite indicates a 7.3 Ma (G. WAGNER; in ALTHERR, 1981). The Laurium granodiorite correlates in age with the granitoids of the Cycladic area. It is of similar age especially with the granodiorite of Serifos (ALTHERR et al., 1982) and the granite into the prevolcanic basement of Thera (SKARPELIS et al., 1992).

Contact metamorphism: Intrusion of the Laurium granodiorite resulted to contact metamorphism of the surrounding "Kaesariani schists". The contact metamorphic aureole comprises undeformed hornfelses and calcic skarns. According to BALTATZIS (1981) the hornfelses were probably formed at temperatures between $440-600^{\circ} \mathrm{C}$ at a pressure of 1.0 to $1.5 \mathrm{~kb}$. The latter estimate was based on geological assumptions by MARINOS \& PETRASCHECK (1956). The pressure estimates for the intrusive rock, based on application of Al-in-hornblende empirical igneous geobarometer, are in the range 2.11 to $2.62 \mathrm{~kb}$.

A magnetite-pyrrhotite skarn-type mineralization with minor scheelite was explored in Plaka area by the French mining company of Laurium (MARINOS \& PETRASCHECK, 1956; LELEU et al., 1973; ECONOMOU et al., 1981). Mineralised skarns of similar type and age in the Cyclades are found in Serifos and Thera islands (SALEMINK, 1985; SKARPELIS \& LIATI, 1990).

Acidic dyke rocks: Undeformed subvertical dykes of acidic rocks striking WNW-ESE to NE-SW crosscut the autochthon system and intrude strata of the allocthon close to the thrust plane. A small number of dykes crosscut the contact metamorphic rocks at Plaka. It is proved that a stage of aplite intrusion occured after the emplacement and solidification of the granodiorite pluton. The acidic rocks are hydrothermally altered and some of them are mineralized. The aplitic dykes may represent magmatic seggregations from the bulk mass of the granodioritic magma. It is worth to be mentioning that a granitic batholith existing at depth in the easternmost part of Attica, was detected by geophysical measurements carried out by MARINOS \& MAKRIS (1975). Aplitic dykes cross-cut previously formed hornfelses in Serifos island as well (SALEMINK, 1985). 
Mineralisation: On the basis of the mode of occurrence, the mineralogy and the textural features of the ore, we may distinguish two types of mineralisation:

a.Hypogene mineralisation (protore) formed as a result of hydrothermal activity.

b.Supergene mineralisation formed due to weathering of the protore.

Mode of occurrence: The main features of the hypogene ore are summarized below, on the basis of published data by MARINOS \& PETRASCHECK (1956) and unpublished data of the author. The Pb-Ag-Zn sulfide mineralisation for which Laurium is famous, bears the typical features of a manto-type ore deposit. The ore is partly conformable, partly crosscutting with respect to the marble and the "Kaesariani schists". The major part of ore bodies occur as massive replacements and linings within the marbles (Fig.2a). Individual deposits occur as irregular pods, lensoid or even grossly discordant vein-like ore bodies. The thickness of the bodies varies from a few $\mathrm{cm}$ to $10 \mathrm{~m}$. Concordant ore bodies are localised within the marbles at their immediate contact with overlying impermeable schists (Fig.2b). In a regional scale the major ore bodies are localised within marble horizons close to the contact of the "lower marble" with the overlying "Kaesariani schists". Relatively smaller ore bodies were explored within marble intercalations in the "Kaesariani schists", or close to the contact of the "upper marble" with the underlying "Kaesariani schists" and also along the thrust zone of the allocthonous system (e.g. Kato Sounio, Plaka). Of special interest is the ore deposit at Plaka, known as "Vein 80" (Fillon 80). It is an E-W striking vein of undeformed massive sulfide ore, dipping $30-45^{\circ} \mathrm{S}$, which crosscuts hornfelses within the contact metamorphic aureole. It is obvious the vein has the same strike as the aplite dykes mentioned above. It was exploited along strike for more than $300 \mathrm{~m}$, mainly due to the high Ag content. The thickness of the ore body varies from a few $\mathrm{cm}$ to $3 \mathrm{~m}$. The ore into the "Vein 80 ' is rythmically banded, indicating filling of open spaces during the opening of the vein. Breccia of the country rock are cemented by sulfides and carbonates.

Wall rock alteration: The most significant alteration associated with the protore is modification of calcitic marble. Such modification ranges from isochemical recrystallization to formation of varieties of ankerite and ankeritic dolomite. Minor silicification was observed in ore bodies of Kamariza mine and also in the fluorite mines of Kato Sounio. Propylitic and sericitic alteration assemblages are observed in the hornfelses.

Mineralogy: Massive sulfide mineralisation comprises various proportions of sulfide minerals with a gangue dominated by carbonates (usually calcite), fluorite and quartz. Fluorite is the latest mineral formed, closely associated with late galena. The ore is undeformed as can be recognised both macro- and microscopically.

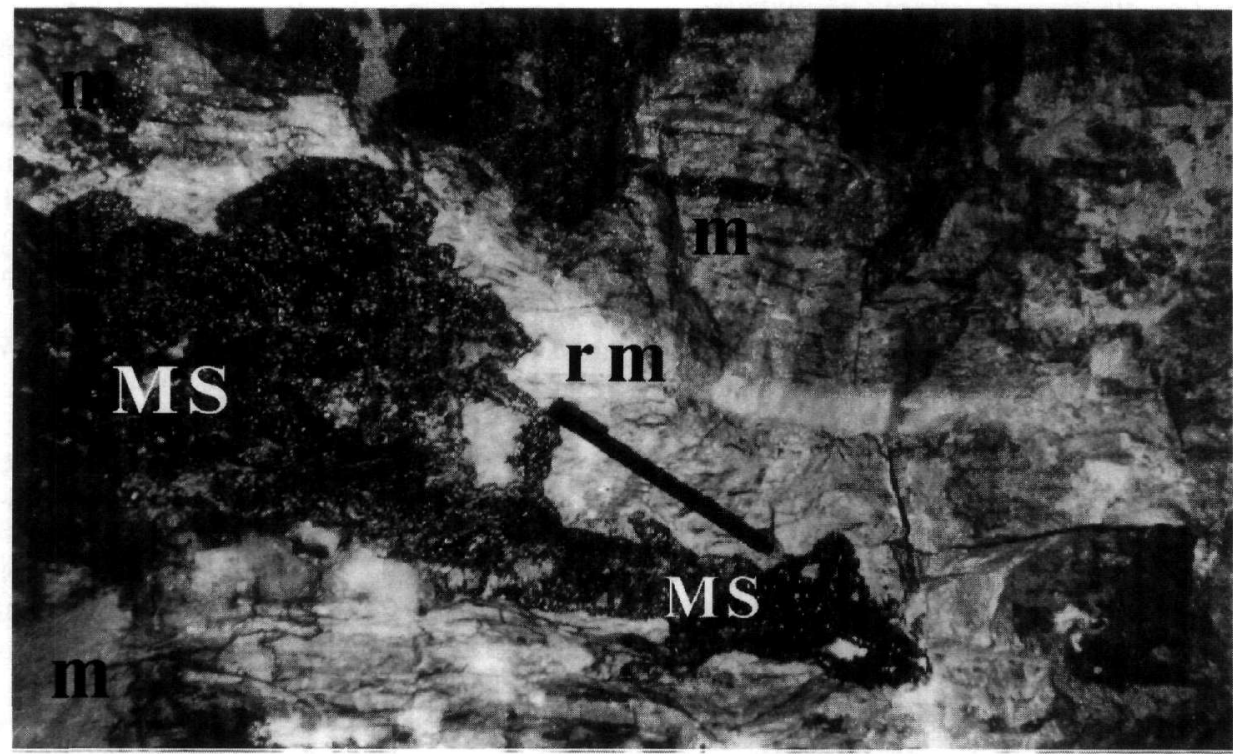

Fig. 2a. Massive sulfides (MS) replacing the lower marble (m) (Kamariza). Note recrystallisation of marble (rm) at the contact with the sulfides. 


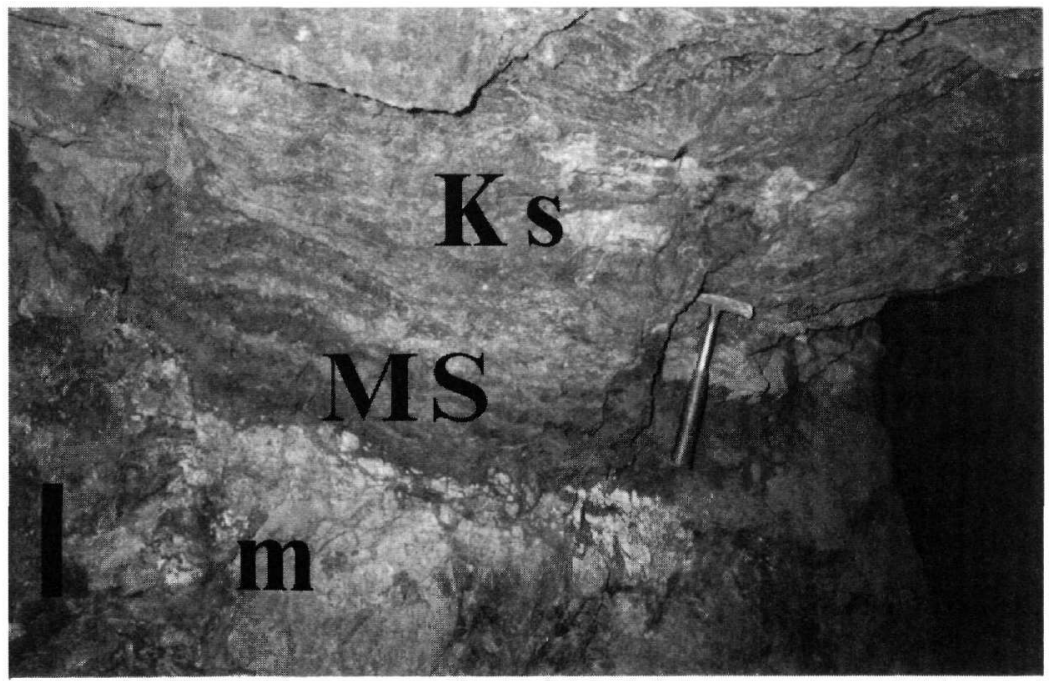

Fig. 2b. Concordant massive sulfide ore body (MS) at the contact of the lower marble $(m)$ with overlying schists (Ks) (Kamariza). Scale bar: $15 \mathrm{~cm}$.

The principal sulfides are galena, sphalerite, pyrite, chalcopyrite and arsenopyrite. Numerous sulfosalts are identified. Gold contents of pure pyrite-arsenopyrite concentrates range from 0.6 to $6 \mathrm{gr} / \mathrm{tn}$. Rarely found native gold grains were formed as a result of liberation of the metal in the course of weathering of arsenopyrite. Nearly all sphalerite in the ores is the high iron variety marmatite. Based on textural relationships, a general paragenetic sequence can be summarized: Pyrite appears to be the earliest formed sulfide, followed by sphalerite, arsenopyrite, chalcopyrite, sulfosalts-galena, carbonates, fluorite and quartz. Fluid inclusion data on sphalerite (SKARPELIS \& LUDERS, in prep.) indicate temperatures around $280^{\circ} \mathrm{C}$. The study of the morphological and geochemical characteristics of the fluid inclusions of fluorites from a vein south of Kamariza (KALOGEROPOULOS \& MITROPOULOS, 1983) indicates fluorite crystals were formed at temperatures ranging from 132 to $208^{\circ} \mathrm{C}$. Salinity values range between 16 to $20 \mathrm{wt} \%$ eq-NaCl.

Weathering of the sulfides: The massive sulfide ores of Laurium are deeply oxidised. Progressive erosion of the landscape and subsequent weathering of the protore, gave rise to supergene mineral assemblages. Two types of supergene mineralisation are distinguished:

a. In situ residual oxidised ore, which resulted by partial or complete weathering of the protore.

b. Secondary ore, deposited in vertical to subvertical fissures of marble and in open spaces (caverns), which were formed as a result of marble dissolution by descending low-pH solutions moving along joints and bedding planes. The oxidation and breakdown of sulfide minerals by groundwater caused significant change in $\mathrm{pH}-\mathrm{Eh}$ environment within and underneath the ore bodies. Lowering of the $\mathrm{pH}$ of percolating/draining ground water caused dissolution of host calcitic marble and development of cavities. Below the ore bodies mobile elements were either temporally held in solution, or precipitate.

The ore bodies, formed by the above described process, comprise a great number of secondary euhedral to subhedral, coarse to medium grained, open space filling minerals. Weathering of sulfides continues today and downward element mobilisation is evident. Acid mine drainage is intense in several parts into the underground mines. The resulting ore bodies were mis-interpreted as karst formations. Both the hypogene sulfides and the supergene ore were exploited since ancient times, mainly for extraction of $\mathrm{Ag}, \mathrm{Pb}, \mathrm{Zn}$ and minor $\mathrm{As}, \mathrm{Cu}, \mathrm{Fe}$. It is worth to be mentioning that on the basis of the amount of $\mathrm{Pb}$ produced since ancient times and the ore grade, it is concluded that the Laurium ore deposit should be considered as a giant within the class of the CHMS type ore deposits.

Remarks on the genesis of hypogene ore: There are no arguments against the model proposed by MARINOS \& PETRASCHECK (1956). The replacement nature of the ore, geometry of ore bodies, wall rock alteration, mineralogy, textures and temperatures of deposition are sufficient evidences allowing classification of the Laurium mineralisation into the carbonate-hosted massive sulfide ore deposit type. A regional metal zonation is not clear in Laurium, both at the vertical and the regional scale. It is evident the Laurium massive sulfides postdate the 
contact metamorphism and skarn formation around the Plaka granodiorite, since veins of massive sulfides crosscut the hornfelses and skarns (Vein 80). A close association of the massive sulfides with the aplitic dykes is evident, since both strike roughly E-W, crosscut the hornfelses and several aplites are mineralised. Geochemical work in progress will improve the genetic model.

\section{c. Mykonos: From granite emplacement to ductile deformation, low-angle faults, brittle faults and epithermal-type mineralisation}

The most significant mining activity in Mykonos - terminated in 1984 - was that of MYKOBAR Mining Co. S.A. for barite from Veins 1 to 5. Small scale sporadic exploitation of iron hydroxides was carried out during the $19^{\text {th }}$ and $20^{\text {th }}$ centuries to the north of Ano Mera village. Cerussite and agglesite were exploited in the hanging wall of the Vein No 1 (Old Italian Workings) and argentiferous galena ore around vein 2 at Mavro Vouno, mainly by open pit mining.

An I-type granite (lower unit) is exposed in the major part of the island, and is characterized by a low-angle NE dipping, solid state foliation which displays a downdip streching lineation. A NE directed extensional motion is indicated by kinematic analysis (FAURE \& BONNEAU, 1988; LEE \& LISTER, 1992). Mylonite zones were developed and low temperature mineral assemblages within cataclasites indicate these structures were formed under brittle-ductile transition. According to BORONKAY \& DOUTSOS (1994) the granite in Mykonos was emplaced during ductile extension, later modified by transpression and transtension under brittle-ductile and brittle conditions. Small patches of HT/LP metamorphic rocks occur in the SW part. An allocthonous unit (upper unit) comprises Permo-Triassic carbonates (PAPASTAMATIOU, 1963), low-grade metabasites (greenschists) and molasse sediments of Oligo-Miocene age (DURR \& ALTHERR, 1979). The contact between the granite and parts either of the molasse or the greenschists (Fig.3) is a low-angle normal fault inclined $\sim 30^{\circ}$ towards NE. In the NE-most part of the island (Cape Evros) the molasse overlies a sliver of greenschists. The granite shows increasing intensity of deformation towards the contact and its mylonitic foliation has been overprinted by cataclasis near and at the contact. K/Ar geochronology on igneous hornblendes and biotites yielded 10 and $12 \mathrm{Ma}$. Fission track thermochronology on apatites yielded ages of 10.0 to $9.5 \mathrm{Ma}$ (DURR et al., 1978; ALTHERR et al., 1982), indicating that mylonitic rocks had been uplifted to shallow levels by 9.5 Ma.

In the area of Panormos bay and at cape Evros the molasse sediments dip towards the low-angle fault. The Panormos and Evros molasse comprise micro-conglomerates and fine to coarse-sandstones. The pebbles are rounded to subrounded and consist of milky quartzite, greenish cherts, quartz-mica schists, and rare phyllite, mica-schists and quartz sandstone. The dark brown colouration of the sediments is mainly due to weathering of iron-sulfides, which impregnated the porous sandstone beds or cemented micro-conglomerates. Fissure filling barite, usually forming stockworks, appears in the mollassic sediments. It is evident that open spaces along joints of the sediment acted as channels for fluid migration and mineral deposition. Barite is associated with (oxidised) pyrite, forming aggregates of platy crystals in pore spaces or in fissures. Thin quartz veins with comb texture are rarely observed.

The granite, the low angle fault and the upper unit are cut by a swarm of subvertical barite-(oxidised) sulfide veins trending $35-45^{\circ} \mathrm{NW}$. Structural analysis of veins indicates they were formed along left lateral, oblique faults. Apophyses of the barite veins are common both in the footwall and the hangingwall and their thickness is minimized several meters far from the main vein. The granitic wallrocks are sericitized and the molassic sediments close to the veins are pervasively silicified. The vein mineralization is banded and consists mainly of barite and Fe-hydroxides. Patches of sulfide minerals can be found at the deepest levels of the veins. The ore comprises barite, pyrite, marcasite, arsenopyrite, chalcopyrite, galena, sulfosalts, low in Fe sphalerite, quartz and supergene minerals. Barite - sulfide ore and the pervasively silicified bedrock have very low Au concentrations

Relics of silicified molassic sediments (silica caps) are preserved on top of the Mavro Vouno hill. Dispersions of argentiferous galena, pyrite, sphalerite, chalcopyrite and sulfosalts are found within the silica cap. The veins crosscut the lower parts of the silica caps. It seems that mineralized solutions passing upwards through the barite-sulfide veins were broadly dispersed, when they entered the porous and permeable detrital molassic rocks. Major parts of the granite in the eastern part of the island are intensely silicified. Significant primary geochemical anomalies of $\mathrm{Pb}, \mathrm{Zn}, \mathrm{Ag}, \mathrm{Sb}, \mathrm{As}$ and $\mathrm{Hg}$ were identified by bedrock geochemistry in the silica cap of Mavro Vouno by LAHTI \& GOVETT (1981), when they carried out an exploration programme aiming to locate sulphide concentrations at depth. Secondary processes (oxidation of sulfides) resulted to dispersion of elements in the surrounding the veins and silica caps areas by fixation to clay minerals and Fe-hydroxides.

Relics of silica breccia are localized on top of the hills in the eastern part of the island (Profitis Elias). 

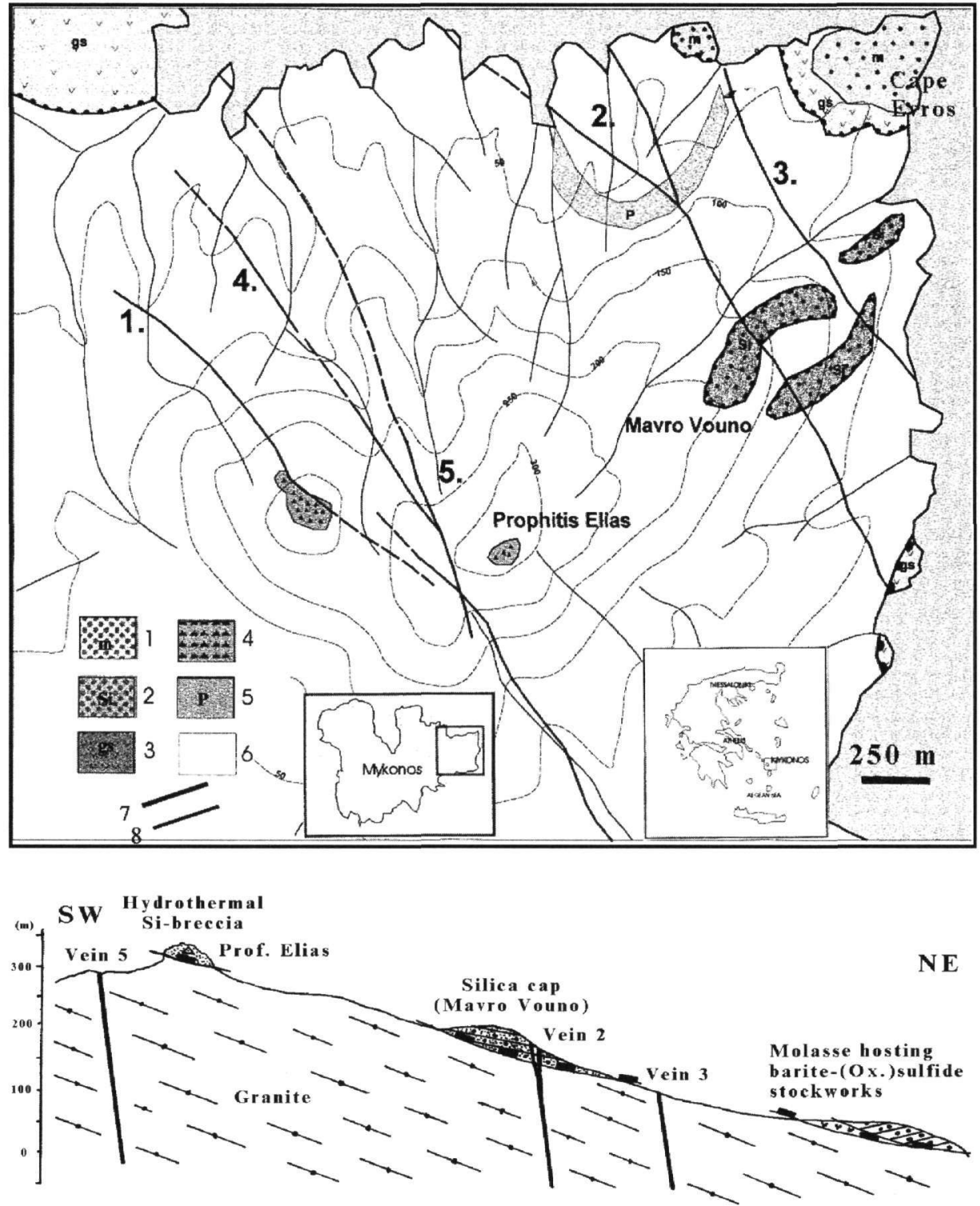

Fig. 3. Geological map and cross-section of the NE part of Mykonos island showing the lithology and the major barite-(oxidised) sulfide veins. (1. Molasse, 2. Silicified molasse, 3. Greenschists, 4. Silica breccia, 5. Poros Aegean, 6. Granite, 7. Barite veins, 8. Low angle fault.

Colloform banding, cockade, crustiform and comb textures are recognized in the matrix. The silica breccia comprise quartz, barite, pyrite, galena, sphalerite and goethite. Gold grades to $1 \mathrm{gr} / \mathrm{tn}$ were detected in the silica breccia on top of the Profitis Elias hills.

A deep oxidation zone was developed, resulting in destruction of sulfide minerals. Preliminary fluid inclusion data indicate temperatures of quartz deposition in the silica breccia around $220^{\circ} \mathrm{C}$. Salinities are very low (3-4 equiv. \% NaCl). Evidently the silica breccia and the silica cap are remnants of a deeply eroded precious metal epithermal type system, which was active in Late Miocene. 


\section{d. Vein-type magnesite deposits in ultramafic rocks in North Euboea: a late Miocene hot spring type epithermal system?}

Although, some very important studies have been published during the last 20 years on the occurrence, mineralogy, and the stable isotope geochemistry of the Greek vein type magnesite deposits in ultramafic rocks (KOCKEL \& MOLLAT, 1976; BURGATH et al., 1981; DABITZIAS, 1980; 1981; LASCHEK, 1982; GARTZOS, 1986; 1990), there are still controversies regarding their genesis and the geodynamic conditions that controlled their formation. The lack of absolute age determination data for this type of mineralisation allows for the genesis problem to remain open. So far, three models have been proposed on the genesis of the magnesite deposits, each of those leading to different conclusions with respect to age and geodynamic conditions. The first model was developed by studying the Vavdos (Chalkidiki) and the northern Euboea magnesite deposits, the second by studying the Vavdos magnesite, and the third one the northern Euboea magnesite. According to those models:

a. The magnesite was formed from supergene processes at the expense of ultramafic rocks (BURGATH et al., 1981; MAKSIMOVIC \& DANGIC, 1984).

b. The magnesite was deposited from ascending fluids rich in $\mathrm{CO}_{2}$. These fluids were generated during dewatering of Mesozoic marine sedimentary rocks underlying the ultramafics (DABITZIAS, 1980).

c. Magnesite deposits were formed from low temperature fluids, which resulted after mixing of ascending $\mathrm{CO}_{2}$ rich fluids with meteoric waters (GARTZOS, 1986; 1990) or by descending fluids, which were slightly heated at depth (LASCHEK,1982).

It is obvious that in the case of the first model, the deposits are considered to have been formed either after the emplacement of the ultramafic rocks, when they were exposed on land (shortly after the Upper Jurassic and before the transgression of the sea in the Upper Cretaceous), or after their emplacement in the present geotectonic position (within the Tertiary). In the second case the genesis of the deposits is related to the obduction of the ultramafic rocks. In the case of the third model, the setting and the similarities of the $\mathrm{C}$ and $\mathrm{O}$ isotopic composition observed between the magnesite and the present day waters of northern Euboea thermal springs, suggest relatively more recent processes.

It is known that central and northern Euboea is largely occupied by Jurassic ophiolitic rocks, mainly hartzburgite and lesser basalts. These rocks overlay a polymictic melange (the Pagondas complex), comprising Upper Triassic to Jurassic sedimentary and volcanic rocks, which was developed as an accretionary prism (ROBERTSON, 1991). The entire sequence of the ophiolitic rocks and the mélange is thrust on the Pelagonian carbonate platform. The ultramafics are covered by Pliocene terrigenous and minor marine and lacustrine sediments, and Quaternary deposits (KATSIKATSOS, 1980). The overthrust Euboea ophiolite is structurally overlain by a dismembered metamorphic sole, that provides evidence for a late Upper Jurassic emplacement age (SPRAY \& RODDICK, 1980; THUIZAT et al., 1981).

The characteristics of the magnesite deposits of northern Euboea can be summarized as follows (for detailed description see the papers by LASCHEK, 1982; GARTZOS, 1986; 1990).

a. Exploration and exploitation data in the area indicate the mineralization is extended to depths of 200-300 m.

b. Magnesite is cryptocrystalline, mostly nodular, and appears as: (i) Open space fillings along joints of ultramafic rocks, forming stockworks. (ii) Veins controlled by brittle faults, indicating that magnesite was deposited during opening of the veins in an extensional geodynamic regime. (iii) Nodular forms, which resulted by replacement of ultramafic rock. Those nodules are mostly centimeter-sized and contain relictic chromite/ spinel. "Cauliflower" or "botryoidal" magnesite textures are predominant in the upper parts of the deposits.

c. Magnesite predates deposition of dolomite and silica polymorphs. A vertical mineral zonation is evident: magnesite modal percentages decrease towards the surface, whereas dolomite and quartz gradually become more abundant. Vuggy silica textures are common in the uppermost parts. Brecciation of early formed magnesite and cementation by magnesite deposited at a later stage is also observed.

d. The deposits, both the stockwork type of mineralisation and the main veins, have not been deformed. Significant displacements by younger faults affecting the deposits are not observed.

e. Structural data systematically recorded from the Geroremma and Paraskevoremma deposits, prove the main veins strike $\mathrm{N} 30-35^{\circ} \mathrm{W}$. The veinlets of the stockwork type of mineralisation show variable trends. Vein swarms trending $\mathrm{N} 30-35^{\circ} \mathrm{W}$ (Fig. 4) indicate clear relation to extensional tectonics. Several thick magnesite veins crosscut stockworks of magnesite. They rather postdate those stockworks and acted as feeders to relatively older (now eroded) ones at higher levels in the deposits. The orientation of the veins follows the brittle fault pattern predominating during the Late Miocene in the Cyclades and the Pelagonian. 


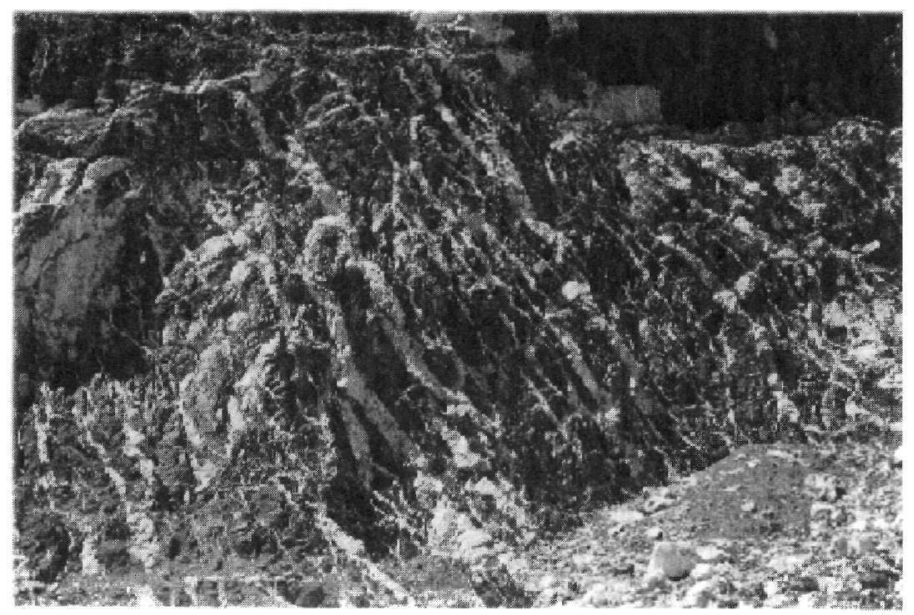

\section{Fig. 4. A swarm of magnesite veins striking $N 30-35^{\circ} \mathrm{W}$ within the ultramafics (Northern sector of the open pit mine Geroremma, Northern Euboea).}

f. The magnesite deposits are deeply eroded. As a result, angular to subangular pebbles and cobbles of magnesite and the host rock, are incorporated within Late Miocene-Pliocene or Quaternary terrestrial sediments. However, detritus of magnesite in pre-Neogene or post-Jurassic sediments are not found.

g. Lateritisation of ultramafic rocks close to the magnesite deposits - mainly observed in the Geroremma deposit - is limited in extend, and postdates the magnesite veins. Minor Ni-rich smectites are identified, whereas complete lateritic profiles lack. It should be noted that the amount of magnesite formed by supergene processes in saprolite horisons of lateritic weathering crusts (GOLIGHTLY, 1981), is extremely small - especially when compared to the tonnage of the vein type magnesite deposits. The Cretaceous and Eocene lateritic weathering crusts in Greece and Albania are characterised by minor stockworks of calcite and dolomite within the saprolite horizon (SKARPELIS, 1997).

The carbon and oxygen isotopic ratios of magnesite were studied by LASCHEK (1982) and GARTZOS $(1986,1990)$. The $\delta^{13} \mathrm{C}_{\mathrm{PDB}}$ ratios of magnesites from the $\mathrm{N}$. Euboean deposits range from -7 to -13 per mill. The oxygen isotopic ratios range from 23 to 30 per mill. These values are close to the Kraubarth-type magnesite isotopic characteristics. They indicate the magnesites were deposited from low temperature $\left(<60^{\circ} \mathrm{C}\right)$ fluids, resulted by mixing of magnesium-bicarbonate waters with ascending $\mathrm{CO}_{2}$ gases (GARTZOS, op.cit.) or by descending fluids which were slightly heated at depth (LASCHEK, opp. cit.). Dolomitization of the veins, extensive precipitation of quartz and alteration of the host rocks are mainly due to ascending $\mathrm{CO}_{2}$ rich waters that followed the degassing phase.

\section{DISCUSSION}

The Cycladic - Pelagonian belt is the result of convergence between the African and Eurasian plates, involving subduction of both oceanic and continental crust. Numerous studies have concentrated on the petrology and geochronology of the metamorphic rocks, especially the blueschists and eclogites in the Cyclades (e.g. SCHLIESTEDT et al., 1987; WIJBRANS \& McDOUGALL, 1988; OKRUSCH \& BROECKER, 1990; AVIGAD et al. 1992; BROECKER, 1993). The Pressure conditions infered are in excess of $15 \mathrm{kbar}$ and the temperatures between 450 and $500^{\circ} \mathrm{C}$ (eclogite to blueschist facies conditions). Termination of the HP metamorphism was a rather diachronous process in the Aegean (Cycladic-Pelagonian belt): before c. 54Ma in the North (Pelagonian), shifting to c. 40Ma in the Cyclades and 20Ma in Crete. The peak of HP metamorphism is interpreted as being Mid-Eocene in age (c. 40-45 Ma), although recent ${ }^{40} \mathrm{Ar} /{ }^{39} \mathrm{Ar}$ laserprobe dating of white mica fabrics, indicate that some of the reported ages do not reflect the metamorphic culmination, but rather the retrograde paths of the HP rocks (LIPS et al., 1999). The Barrovian HT/LP overprint resulted to replacement of the HP rocks at pressures between 4-7 kbar in the Cyclades, within a time span from 25-20 Ma. The end of ductile deformation in the Pelion Massif occurred at c. $15 \mathrm{Ma}$ (LIPS et al., op. cit). Thus the regionally observed phase of Early Miocene extension and subsequent termination of ductile deformation appears to be roughly synchronous across the region. Back-arc extension in the Aegean region began at least in the Early Miocene. Early Miocene extensional 
tectonics were superimposed on crustal material. Low-angle fault systems were developed at crustal levels and gradually exhumed to upper crustal levels and the surface. Part of the Aegean basement was exhumed during the mid-late Miocene. Detachment faulting has been accompanied by emplacement of syn-tectonic granodiorites and granites and development of contact metamorphic aureoles. Dating of the granitoids indicates different magma pulses within the late Miocene ( $15 \mathrm{Ma}$ to $9 \mathrm{Ma}$ ) (ALTHERR, 1981), with the youngest granitoids towards the W and SW parts of the belt (Laurium, Serifos, Thera). Emplacement of the granitoids took place at different depths within the Cycladic region, as it is proved by applying the Al-in-hornblende empirical igneous geobarometer. The pressure estimates of the Laurium granodiorite are in the range 2.11 to $2.62 \mathrm{~kb}$, which are higher in comparison to pressure estimates for the mafic enclaves ( 1.0 to $2.2 \mathrm{~kb})$ and the granodiorite ( 0.33 to 1.7 $\mathrm{kb}$ ) for the Serifos intrusion (STOURAITI \& MITROPOULOS, 1999), and lower than the Tinos monzogranite (3.7 to $4.2 \mathrm{~kb}$ ) (BROECKER \& FRANZ, 1994).

The various mineralisation types in the Cycladic and Pelagonian Belt are associated with the succesive stages of tectono-plutonic evolution of the area. The sequence of events associated with the emplacement and subsequent cooling of the Cycladic granitoids is indicative of evolution at shallow crustal levels. Contact metamorphic aureoles were formed during uplift at shallow levels in the crust relative to deeper levels of emplacement of the plutons (see Table $1 \mathrm{~b}$ for depths of formation). The intrusive contacts are sharply discordant to bedding of neighbouring rocks. The granitoids with which skarns are associated belong to the I-type magnetite series (Laurium, Serifos, Thera, Tinos). Skarns massively replaced hornfelses, whereas a retrograde stage resulted in destruction of part of the skarn along brittle fractures, indicating strong hydrofracturing typical of skarns formed at shallow depths. The presence of acidic igneous dyke rocks along extensional faults cross-cutting previously formed hornfelses and skarns in Laurium and in Serifos, points to the existence of residual liquid granodioritic magma at relatively deeper parts. The E-W and NW-SE vein type massive sulfide mineralisation cross-cutting hornfelses and skarns in Laurium (Vein 80) and Thera respectively, indicates that intense hydrothermal activity followed the HT skarn stage.

Laurium is a region where a temporal evolution of mineralisation can be detected: emplacement of the granitic batholith and the granodiorite at shallow crustal levels was followed by contact metamorphism at shallower levels and by injection of acidic rocks along WNW-ESE to NE-SW extensional faults. Replacements of marbles by ascending hydrothermal fluids and deposition of carbonate-hosted massive sulfides accompanied skarn formation. Absolute dating of the massive sulfide mineralisation is lacking. Taking under consideration the geology of the deposit and the available radiometric data, it is reasonable to conclude that the Laurium carbonate hosted massive sulfides were formed in the latest Miocene.

Late stages of extensional tectonics resulted in the formation of vertical to subvertical fault zones, which were then used as conduits for ascending hydrothermal fluids. The main structural features of the fault controlled vein type mineralisations in the Cyclades and Pelagonian are summarised as follows:

a. The trends of brittle faults broadly cluster into two groups: a NW-SE, and a roughly E-W. Geochronological data associated with the NW-SE faults lack. Some of them should be older than the Tinos 11.5 Ma dacitic dyke rocks. On Tinos the mineralized ductile to brittle quartz veins seem to predate the dacitic dykes, being probably associated with the leucogranite. The apatite fission track ages of 10.0 and $9.5 \mathrm{Ma}$ obtained from samples of the Mykonos granite by ALTHERR et al. (1982), suggest that by 9.5 Ma ductile deformation had ceased and mylonitic rocks had been uplifted to shallow levels of the crust in the footwall of the normal fault (LEE \& LISTER, 1992). The dating indicates that the barite veins and the epithermal type mineralisation in the island are younger than $9.5 \mathrm{Ma}$.

The E-W trending faults associated with the acidic dykes and the "Vein 80 " in Laurium postdate the contact metamorphic phaenomena, caused by the intrusion of the $\sim 9$ Ma granodiorite. A similar to the Laurium setting is reported for the (oxidised) $\mathrm{Pb}$-Ag massive sulfide mineralisation on Sifnos island (e.g. Agios Sostis, Agios Silvestros) (SKARPELIS, unpubl.). These mineralisations are vein-like bodies, striking NE-SW to ENE-WSW, replacing marbles of the blueschist unit. A possibility exists that the Laurium region was under a different stress regime during the latest Miocene relative to the neighbouring Cycladic - Pelagonian "crustal block" (West Aegean Block, as defined by WALCOTT, 1998). Alternatively the Laurium dyke rocks and "Vein type" massive sulfide ore bodies are associated with the most recent (latest Miocene?) 032 extension, developed in brittle conditions.

b. They bear extensional characteristics and crosscut the lower and upper tectonic units, the granitoid rocks and the low angle faults. Palaeomagnetic studies indicate that the dacitic dykes in Tinos have experienced a $23^{\circ}$ vertical axis clockwise rotation (AVIGAD et al., 1998). Clockwise rotations were detected in Euboea and Mykonos by KISSEL \& LAJ (1988) and MORRIS \& ANDERSON (1996). The present setting of the NW-SE trending 
veins, which appear in a broad region extended from Antiparos to north Euboea, indicates they shared the same tectonic evolution.

The geology of the vein-type epithermal mineralisations indicates that the heat engines necessary for fluid generation should be magma bodies at depth. In the case of the remnants of the epithermal system of Mykonos it is obvious there is no link with any outcrop of volcanic rocks. It seems that mineralised hydrothermal fluids linked a deep-seated plumbing system with very shallow crustal levels and the surface (SKARPELIS \& AVIGAD, 2000).

POHL (1990) after a comprehensive review of the setting, mineralogy and geochemistry of vein type magnesite deposits in ultramafic rocks, proposed a model of epithermal "hot spring" style of mineral deposition. In the case of the magnesite deposits in N. Euboea, the fluids could be driven by a heat source located at depth. It is possible that the magnesite depositing fluids were driven by volcanically induced heat flow, that was related to the Miocene or younger volcanism in the area. The exposed volcanic rocks in Euboea and the adjacent islands are Miocene to Quaternary in age (FYTIKAS et al., 1984; PE-PIPER \& PIPER, 1994).

Further mineralogical and geochemical studies will extend our knowledge on the origin of fluids and the conditions of deposition of ore mineralisation, especially of the group of epithermal precious and base metals quartz- and barite-veins.

\section{ACKNOWLEDGMENTS}

The financial support of part of the research work by the University of Athens (Special Account for Research Grands) is kindly acknowledged.

\section{REFERENCES}

ALEXOULI-LIVADITI, A. (1978) Combined sulfide ores of Kallianou area, S. Euboea: geology, petrography, ore deposit geology. Thesis, Faculty of Min. \& Metal. Eng., Technical University of Athens, 117 p., Athens.

ALTHERR, R. (1981) Zur Petrologie der Miozanen Granitoide der Zentral-agais (Griechenland). Dr. habil. Thesis, Univ. Braunschweig, Germany, 218p.

ALTHERR, R., KREUZER, H., WENDT, I., LENZ, H., WAGNER, G.A., KELlER, J. HARRE, W. \& HOHNDORF, A. (1982) A Late Oligocene/Early Miocene high temperature belt in the Attic-Cycladic crystalline complex (SE Pelagonian, Greece). Geol. Jb., E23, 97-164.

AVIGAD, D. \& GARFUNKEL, Z. (1989) Low-angle faults below and above a blueschist belt - Tinos island, Cyclades, Greece. Terra Nova 1, 182-187.

AVIGAD, D., BAER, G. \& HEIMANN, A. (1998) Block rotations and continental extension in the central Aegean Sea: paleomagnetic and structural evidence from Tinos and Mykonos. E.P.S.L. 157, 23-40.

AVIGAD, D., MATTHEWS, A., EVANS, B.W. \& GARFUNKEL, Z. (1992) Cooling during the exhumation of a blueschist terrane: Sifnos (Cyclades, Greece). European Journal of Mineralogy, 4, 619-634.

BALTATZIS, E. (1981) Contact metamorphism of a calc-silicate hornfels from Plaka area, Laurium, Greece. N. Jb. Miner. Mh. 11, 481-488.

BALTATZIS, E. (1996) Blueschist-to-greenschist transition and the $P-T$ path of prasinites from the Lavrion area, Greece. Min. Mag., 60, 551-561.

BAVAY, Ph. \& ROMAIN-BAVAY, D. (1980) L' unite de Styra - Ochi. Un ensemble metamorphique de type schistes bleus d' age alpin dans le massif d' Attique - Cyclades (Eubee du sud, Grece). These 3eme Cycle, Univ. Paris Sud, 369 p., Orsay.

BEATY, D.W., CUNNINGHAM, C.G., RYE, R.O., STEVEN, T.A. \& GONZALEZ-URIEN, E. (1986) Geology and Geochemistry of the Deer Trail Pb-Zn-Ag-Au-Cu Manto Deposits, Marysvale District, West-Central Utah. Econ. Geol., 81, 1932-1952.

BLAKE, M.C., JR, BONNEAU, M., GEYSSANT, J., KIENAST, J.R., LEPVRIER, G., MALUSKI, H. \& PAPANIKOLAOU, D. (1981) A geologic reconnaissance of the cycladic blueschist belt, Greece. Geological Society of America, 92, 247-254.

BORONKAY, K. \& DOUTSOS, T. (1994)Transpression and transtension within different structural levels in the central Aegean region. J. Struct. Geology, 16, 1555-1573

BROECKER, M. (1990) Blueschist-to-greenschist transition in metabasites from Tinos Island, Cyclades, Greece: Compositional control or fluid infiltration? Lithos, 25, 25-39

BROECKER, M. \& FRANZ, L. (1994) The Contact Aureole on Tinos (Cyclades, Greece). Part I: Field Relationships, petrography and PT Conditions. Chem. Erde 54, 262-280. 
BROECKER, M. \& FRANZ, L. (1998) Rb-Sr isotope studies on Tinos Island (Cyclades, Greece): additional time constrains for metamorphism, extent of infiltration-controlled overprinting and deformational activity. Geol. Mag. 135, 369-382,

BROECKER, M. \& FRANZ, L. (2000) The contact aureole on Tinos (Cyclades, Greece): tourmaline-biotite geothermometry and Rb-Sr geochronoloy. Min. and Petrol., 70, 257-283.

BROECKER, M., KREUZER, A., MATTHEWS, A. \& OKRUSCH, M. (1993) ${ }^{40} \mathrm{Ar} /{ }^{39} \mathrm{Ar}$ and oxygen isotope studies of polymetamorphism from Tinos Island, Cycladic blueschist belt, Greece. J. metamorphic Geol., 11, 223-240.

BURGATH, K., GRISSEMANN, C., JOHANNES, W., JUNG, D., KNOLKE, H., KOCKEL, F., MAKRIS, J., MOHR, M., MUSSALAM, K. \& RASCHKA, H. (1981) On the Genesis of magnesite deposits in Northern Greece. In: Proc. UNESCO International Symposium on Metallogeny of mafic and ultramafic complexes, 3 , 226-239.

DABITZIAS, S. (1980) Petrology and Genesis of the Vavdos Cryptocrystalline Magnesite Deposits, Chalkidiki Peninsula, Northern Greece. Econ. Geol., 75, 8, 1138-1151.

DABITZIAS, S. (1981) Additional evidence and a synopsis on the origin of the magnesite deposits in the Vavdos district, Northern Greece. In: Proc. UNESCO International Symposium on Metallogeny of mafic and ultramafic complexes, 3, 269-283.

DURR, S. \& ALTHERR, R. (1979) Existence des klippes d' une nappe composite neogene dans l' ile de Myconos / Cyclades (Grece). Rapp. Comm. int. Mer Medit., 25/26/2a, 33-34.

DURR, St., ALTHERR, R., KELLER, J., OKRUSCH, M. \& SEIDEL, E. (1978) The Median Aegean Crustalline Belt: stratigraphy, structure, metamorphism, magmatism. In: Alps, Apennines, Hellenides (eds Closs, H., Roeder, D.H. \& Schmidt, K), 455-477. Schweizerbart, Stuttgart.

ECONOMOU, M., SKOUNAKIS, S. \& PAPATHANASIOU, C. (1981) Magnetite deposits of skarn type from the Plaka area of Laurium, Greece. Chemie der Erde 40, 241-252.

ENGEL, M. \& REISCHMANN, T. (1999) Geochronology of the pre-Alpine Basement in the Central Cyclades, Greece. EUG 10, Strasbourg, Abstract volume, 806.

FAURE, M. \& BONNEAU, M. (1988) Donnees nouvelles sur l' extension neogene de l' Egee: la deformation ductile du granite miocene de Mykonos (Cyclades, Grece). C. R. Acad. Sci. Paris, 307, 1553-1559.

FYTIKAS, M., INNOCENTI, F., MANETTI, P., MAZZUOLI, R., PECCERILLO, A. \& VILLARI, L. (1984) Tertiary to Quaternary evolution of volcanism in the Aegean region. In: DIXON, J.E. \& ROBERTSON, A.H.F. (eds). The geological evolution of the eastern Mediterranean. Geological Society, Special Publication, 17, 687-699.

GARTZOS, E. (1986) On the genesis of cryptocrystalline magnesite deposits in the ultramafic rocks North Evia. PhD Thesis, ETH Zurich, $195 \mathrm{p}$.

GARTZOS, E. (1990) Carbon and oxygen irotope constraints on the origin of magnesite deposits, North Evia (Greece). Schweiz. Mineral. Petrogr. Mitt. 70, 67-72.

GOLIGHTLY, J.P. (1981) Nickeliferous Laterite Deposits, Economic Geology $75^{\text {th }}$ Anniversary Volume, 710735.

KALOGEROPOULOS, S. \& MITROPOULOS, P. (1983) Fluid inclusion characteristics of fluorite from Laurium (Greece). Ann. Geol. Pays Hell., 31, 130-135.

KATSIKATSOS, G. (1980) Geological map, sheet LIMNI, scale 1:50.000, I.G.M.E., Athens.

KATSIKATSOS, G., MIGIROS, G., TRIANTAFYLLIS, E. \& METTOS, A. (1986) Geological structure of internal Hellenides (E. Thessaly - SW Macedonia, Euboea - Attica - Northern Cyclades Islands and Lesbos). Geol. \& Geoph. Res., Special Issue, I.G.M.E., 191-212, Athens.

KATZIR, Y., MATTHEWS, A., GARFUNKEL, Z. \& SCHLIESTEDT, M. (1996) The tectono-metamorphic evolution of a dismembered ophiolite (Tinos, Cyclades, Greece). Geol. Mag. 133, 237-254.

KISSEL, C. \& LAJ, C. (1988) The Tertiary geodynamical evolution of the Aegean Arc: a paleomagnetic reconstruction. Tectonophysics, 146, 183-201.

KOCKEL, F. \& MOLLAT, H. (1976) Untersuchungen an der Magnesitvererzungen in der westlichen Chalkidiki (N. Griechenland). Geol. Jahrb. 16, 29-57.

KORNBROBST, J., KIENAST, J.R. \& VILMINOT, J.-C. (1979) The high-pressure assemblages at Milos, Greece. Contrib. Mineral. Petrol., 69, 49-63.

LAHTI, H.R. \& GOVETT, G.J.S. (1981) Primary and secondary halos in weathered and oxidized rocks - An exploration study from Myconos, Greece. J. Geochem. Explor., 16, 27-40.

LASCHEK, D. (1982) Geochemische- und Isotopenuntersuchungen zur Genese der Magnesitlagerstatten 
Mitteleuboeas, Griechenland. Unpublished Diplomwork, Universitat Karlsruhe, 83p.

LEE, J. \& LISTER, S. G. (1992) Late Miocene ductile extension and detachment faulting, Mykonos, Greece. Geology, 20, 121-124.

LELEU, M. \& NEUMMAN, M. (1969) L' âge des formations d' Attique: du paleozoique au mesozoique. C. R. Ac. Sci. Paris, 268, 1361-1363.

LELEU, M., MORIKIS, A. \& PICOT, P. (1973) Sur des mineralisations de type skarn au Laurium (Greece). Mineral. Deposita, 8, 259-263.

LIPS, A.L.W. (1998) Temporal constraints on the kinematics of the destabilization of an orogen; syn- to postorogenic extensional collapse of the Northern Aegean region. PhD Thesis, University of Utrecht, Geologica Ultrajectina 167, 220p.

LIPS, A.L.W., WIJBRANS, J.R. \& WHITE, S.H. (1999) New insights from ${ }^{40} \mathrm{Ar} /{ }^{39} \mathrm{Ar}$ laserprobe dating of white mica fabrics from the Pelion massif, Pelagonian Zone, Internal Hellenides, Greece: implications for the timing of metamorphic episodes and tectonic events in the Aegean region. In: Durand, B., Jolivet, L., Horvath, F. \& Seranne, M. (eds), Geological Society, London, Special Publication No 156, 457-474.

MAKSIMOVIC, Z. \& DANKIC, A. (1984) Mercury in Neogene hydrothermal systems in the Balkan Peninsula and genesis of magnesites. Proc. $6^{\text {th }}$ Quadrennial IAGOD Symposium, 149-153.

MARAKIS, G. (1968) Remarks on the age of sulfide mineralisation in Cyclades area. Ann. Geol. Pays Hellen., 19, 695-700.

MARINOS, G. (1971) On radiometric dating of rocks of Greece, Ann. Geol. Pays Hellen., 23, 175-182.

MARINOS, G. \& MAKRIS, J. (1975) Geological and geophysical considerations of new mining possibilities in Laurium, Greece. Ann. Geol. Pays Hellen., 27, 1-10.

MARINOS, G. \& PETRASCHECK, W.E. (1956) Laurium. Geological and Geophysical Research, Institute for Geology and Subsurface Research, IV, 1, 246p.

MASTRAKAS, N. \& SEYMOUR, St., K. (2000) Geochemistry of Tinos granite: A window to the Miocene microplate tectonics of the Aegean region. N. Jb. Miner. Abh. 175, 295-315

MELIDONIS, N. (1980) The geological structure and ore deposit geology of Tinos island, Cyclades, Greece. I.G.M.E., Geol. \& Geoph. Res. 13, 1-80, Athens.

MORRIS, A. \& ANDERSON, M. (1996) First palaeomagnetic results from the Cycladic Massif, Greece, and their implications for Miocene extension directions and tectonic models in the Aegean. E.P.S.L. 142, 397-408.

MOUNTRAKIS, D. (1986) The Pelagonian zone in Greece: a polyphase-deformed fragment of the Cimmerian Continent and its role in the geotectonic evolution of the Eastern Mediterranean. J. Geol. 94, 335-347.

OKRUSCH, M. \& BROECKER, M. (1990) Eclogites associated with high-grade blueschists in the Cycladic archipelago, Greece: a review. Eutopean Journal of Mineralogy, 2, 451-478.

PAPANIKOLAOU, D. (1987) Tectonic evolution of the Cycladic blueschist belt (Aegean sea, Greece). In: Chemical Transport in Metasomatic Processes. Helgeson, H.C. (ed.), 429-450, Reidel Publishing Company.

PAPANIKOLAOU, D. \& SYSKAKIS, D. (1991) Geometry of acid intrusives in Plaka, Laurium and relation between magmatism and deformation. Bull. Geol. Soc. Greece, 25, 1, 355-368.

PAPASTAMATIOU, I. (1963) Sur la presence des roches sedimentaires d' age pre-triassic a Myconos. C.R.Ac. Sc., 256, 5167-69, Paris.

PAPASTAVROU, S. \& PARITSIS, S. (1990) Volcanic hosted W-mineralization on the island of Tinos, Cyclades, Greece. Proceedings IESCA 1990, Savascin, M.Y. \& Eronat, A.H. (ed.) 2, 59-73.

PATZAK, M. OKRUSCH, M. \& KREUZER, H. (1994) The Akrotiri Unit on the island of Tinos, Cyclades, Greece. witness to a lost terrane of late Cretaceous age. N. Jb. Geol. Palaeontol. Abh 194, 211-252.

PE-PIPER, G. \& PIPER, D.J.W. (1994) Miocene magnesian andesites and dacites, Evia, Greece: adakites associated with subducting slab detachment and extension. Lithos, 31, 125-140.

POHL, W. (1990) Genesis of Magnesite Deposits - Models and Trends. Geol. Rundschau, 79, 2, 291-299.

ROBERTSON, A.H.F. (1991) Origin and emplacement of an inferred late Jurassic subduction-accretion complex, Euboea, eastern Greece. Geol. Mag. 128 (1), 27-41.

SALEMINK, J. (1985) Skarn and Ore formation at Seriphos, Greece, as a consequence of granodiorite intrusion. Geologica Untrajectina, Univ. Utrecht, No 40, 231p.

SCHLIESTEDT, M., ALTHERR, R. \& MATTHEWS, A. (1987) Evolution of the cycladic crystalline complex: petrology, isotope geochemistry and geochronoloy. In: Chemical Transport in Metasomatic Processes, Helgeson, H.C. (ed.), 389-428, Reidel Publishing Company.

SHERMER, E., LUX, D. \& BURCFEIL, B.C. (1989) Age and tectonic sugnificance of metamprphic events in the Mt. Olympos region, Greece. Bull. Geol. Soc. Greece, 28, 1, 13-27. 
SKARPELIS, N. (1997) Eocene nickel laterite deposits in Greece and Albania. In: Mineral Deposits, Papunen (ed.), 503-506, Balkema, Rotterdam.

SKARPELIS, N. \& AVIGAD, D. (2000) Mineralisation associated with back-arc extension in the central Aegean region. ABCD-GEODE 2000 Workshop, Abstracts Vol., p. 77, Borovets, Bulgaria.

SKARPELIS, N., KYRIAKOPOULOS, K. \& VILLA, (1992) Occurrence and ${ }^{40} \mathrm{Ar} /{ }^{39} \mathrm{Ar}$ dating of a granite in Thera (Santorini, Greece). Geol. Rundschau 81, 3, 729-735.

SKARPELIS, N. \& LIATI, A. (1990)The prevolcanic basement of Thera at Athinios: Metamorphism, Plutonism and Mineralisation. Proc. $3^{\text {rd }}$ International Gongress "Thera and the Aegean world", Hardy, D. A. (ed.), The Thera Foundation, London, 2, 172-182.

SPRAY, J.G. \& RODDICK, J.C (1980) Petrology and ${ }^{40} \mathrm{Ar} /{ }^{39} \mathrm{Ar}$ Geochronology of some Hellenic Sub-Ophiolite Metamorphic Rocks. Contrib. Mineral. Petrol. 72, 43-55.

STOURAITI, CH. \& MITROPOULOS, P. (1999) Variation in amphibole composition from the Serifos intrusive complex (Greece), under magmatic and hydrothermal conditions. An application of hornblende geobarometry. Bull. Geol. Soc. Greece, 33, 39-50.

THUIZAT, R., WHITECHURCH, H., MONTIGNY, R. \& JUTEAU, T. (1981) K-Ar dating of some infra-ophiolitic metamorphic soles from the Eastern Mediterranean: New evidence for oceanic thrustings before obduction. E.P.S.L., 52, 302-310.

TOMBROS, S. \& SEYMOUR, St., K. (1998) Applied geothermometry of the hydrothermal Au-Ag vein mineralization, Apigania, Tinos. Bull. Geol. Soc. Greece, 32, 3, 165-172.

VAVASSIS, I., DE BONO, A., STAMPFLI, G.M., GIORGIS, D., VALLOTON, A. \& AMELIN, Y. (2000) U-Pb and Ar-Ar geochronological data from the Pelagonian basement in Evia (Greece): geodynamic implications for the evolution of Paleotethys. Schweiz. Mineral. Petrogr. Mitt., 80, 21-43.

WALCOTT, C.R. (1998) The Alpine Evolution of Thessaly (NW Greece) and late Tertiary Aegean kinematics. $\mathrm{PhD}$ Thesis, University of Utrecht, Geologica Ultrajectina 162, 176p.

WIJBRANS, J.R. \& McDOUGALL, I. (1988) Metamorphic evolution of the Attic-Cycladic metamorphic belt on Naxos (Cyclades, Greece). J. Metam. Petrol., 6, 571-594. 